Accepted Manuscript (AM) of King, R., Lulle, A., Sampaio, D. and Vullnetari, J. (2016) Unpacking the ageing-migration nexus and challenging the vulnerability trope. Journal of Ethnic and Migration Studies [DOI: TBC][accepted June 2016; anticipated to be published online August 2016].

\title{
Unpacking the ageing-migration nexus and challenging the vulnerability trope
}

Russell King (corresponding author)

Department of Geography, University of Sussex

Brighton, BN1 9RH

United Kingdom

Email: R.King@sussex.ac.uk

Tel: +441273678744

Aija Lulle

Department of Geography, University of Sussex

Brighton, BN1 9RH

United Kingdom

Email : A.Lulle@sussex.ac.uk

Dora Sampaio

Department of Geography, University of Sussex

Brighton, BN1 9RH

United Kingdom

D.Sampaio@sussex.ac.uk

Julie Vullnetari

Department of Geography and Environment, University of Southampton

University Road

Southampton

SO17 1BJ, United Kingdom

Tel: +44 2380596710

Email: J.Vullnetari@soton.ac.uk 
Accepted Manuscript (AM) of King, R., Lulle, A., Sampaio, D. and Vullnetari, J. (2016) Unpacking the ageing-migration nexus and challenging the vulnerability trope. Journal of Ethnic and Migration

Studies [DOI: TBC][accepted June 2016; anticipated to be published online August 2016].

\section{Abstract}

The nexus between ageing and migration throws up a variety of situations. In this paper we map out the various circumstances in which ageing and migration fuse together as entwined trajectories to produce situations of vulnerability, coping, active ageing, and variable wellbeing. The ageing process is seen to be socially constructed and culturally embedded; hence place - at 'home' or 'abroad', or some transnational mix - becomes a paramount structuring variable. Different models of successful ageing compete as migrants move and age in different countries and different cultures; the western model of individual self-reliance should not necessarily be imposed on ageing migrant populations. In the final part of the article we challenge the prevailing trope of vulnerability applied to the perceived double disadvantage of being both an older person and a migrant, and present four case-studies in which older migrants enact agency and independence to achieve a greater level of material and subjective well-being.

Keywords: Migrants, Ageing, Agency, Vulnerability, Transnational care, Well-being

Word count: 161 (abstract) +9976

[The Version of Record of this manuscript has been published and is available in Journal of Ethnic and Migration Studies; anticipated to be published online August 2016 [DOI: TBC]. 
Accepted Manuscript (AM) of King, R., Lulle, A., Sampaio, D. and Vullnetari, J. (2016) Unpacking the ageing-migration nexus and challenging the vulnerability trope. Journal of Ethnic and Migration

Studies [DOI: TBC][accepted June 2016; anticipated to be published online August 2016].

\section{Introduction}

Most studies of migration assume the protagonists to be young or early-middle-age adults who move abroad to improve their life-chances, and those of their children, by accessing better-paid jobs and enhancing their careers; older people, including the parents of the migrants, are left in the shadows, overlooked by the mainstream scholarship on migration. Meanwhile, most studies of older people construct the ageing process as marked by sedentarism, vulnerability, and physical and mental decline. This paper, whilst aspiring to be a state-of-the-art on the nexus between migration and ageing, seeks to challenge the dual discursive framing referred to above.

The processes of ageing and migration are seen as entwined trajectories which unfold with specific results in different times and spaces. Older migrants, or older people affected by the migration of others, may indeed endure multiple dimensions of vulnerability, but they are also often able to enact their own agency, either as active participants in migration, or through coping mechanisms which are logical responses to the other ways in which they are imbricated in the wider migration processes of their families and communities. Increasingly globalised migration movements and the consequent transnationalisation of family lives create new social phenomena at the intersection of ageing and migration. The most obvious of these are issues relating to care, duty and affect, but also important are new communications technologies, business initiatives, and reactive and transformative everyday life practices geared to responding to the challenges of managing ageing and care across transnational spaces (Baldassar, Baldock and Wilding 2007).

The paper develops as follows. First we look at how the notions of 'old age' and 'ageing' are socially constructed and culturally embedded. Then we bring in migration and the inevitable transnational entanglement of older people's lifeworlds. We categorise the diverse situations in which the entwined trajectories of ageing and migration express themselves across time, space and place, with variable impacts on vulnerability, positive ageing, and material and subjective well-being. In the final part of the paper we present four case-histories of positive and creative ageing in situations of migration in order to counter the dominant trope of vulnerability which surrounds most existing studies and policies on older migrants. 
Accepted Manuscript (AM) of King, R., Lulle, A., Sampaio, D. and Vullnetari, J. (2016) Unpacking the ageing-migration nexus and challenging the vulnerability trope. Journal of Ethnic and Migration

Studies [DOI: TBC][accepted June 2016; anticipated to be published online August 2016].

\section{What is ageing?}

Both ageing and migration are truly interdisciplinary phenomena, cutting across not only the full range of social sciences but also the humanities and the health and natural sciences. This creates a potentially wide range of theoretical angles and methodological approaches for studying the interactions between migration and ageing. International migration is a relatively unambiguous phenomenon - it involves crossing an international border and a certain minimum threshold of stay in the destination country. Ageing is a much more contested and slippery process to define and conceptualise, with major disagreements in the literature about how it should be analysed.

It is widely accepted that, after a certain stage in their lives, people start being labelled as 'aged', 'old' or 'elderly'. Despite its arbitrary nature and lack of intrinsic meaning, chronological age continues to be used to define this threshold, and precisely because of its institutional deployment (eg. as 'pensionable' age) it effectively has the power to influence the lives of individuals (Bytheway 2005). Following the seminal work of Neugarten (1974), it can be acknowledged that attempting to fix boundaries between 'young', 'middle-aged' and 'old' is both artificial and problematic. Rather, as many authors have argued, a more embodied approach is more useful in examining ageing. More realistic are certain life-course events which, whilst being themselves socially and economically constructed (Pain, Mowl and Talbot 2000), yield an approach which is more flexible and sensitive to the diversity of pathways that individuals follow during their lives. Advocacy of a lifecourse approach to the study of ageing in a migratory context enables ageing and space/place to be captured as 'entwined becomings' (Schwanen, Hardill and Lucas 2012).

Focusing on the individual dimension of the ageing process, several authors have referred to the so-called Cartesian division: on the one hand the ageing body which inevitably grows old and is regarded as unproductive, especially in valuemeasured capitalist societies; and on the other hand, the spirit that remains continuously young (Andrews 1999; Harper and Laws 1995). This division is highlighted by the apparent contradiction between traditional stereotypes associating older age with idleness, mental and physical incapacity and dependency, 
Accepted Manuscript (AM) of King, R., Lulle, A., Sampaio, D. and Vullnetari, J. (2016) Unpacking the ageing-migration nexus and challenging the vulnerability trope. Journal of Ethnic and Migration

Studies [DOI: TBC][accepted June 2016; anticipated to be published online August 2016].

and the increasing spread of lifestyle models guided by principles of independence and 'healthy' ageing (Bytheway 2000).

Some authors (especially Gibson 2000) are very critical of the mind-body split, arguing instead for a 'unified whole' rather than the division (even conflict) between an individual's ageing physical appearance and the 'youthful spirit' that remains undimmed by the passing of time. Especially amongst baby-boomers, ageing is masked by a social façade created by a consumer culture designed to obscure the physical and social manifestations of age (Featherstone and Hepworth 1989). According to Biggs $(1997,568)$, 'mid-lifestylism' should be seen as a problem rather than a solution to the challenges of later life 'because it constitutes a hanging on to an illusion, and an avoidance of existential questions that have to be asked in the second half of life'. The current celebration of later-lifers 'growing old disgracefully' in popular culture and the media draws a veil over the very real biological and mental frailties that ultimately ensue, and is set in opposition to the crisis in care of the very old and frail in societies which are less family-oriented and where the welfare state struggles to cope with the needs of an ageing population.

The individualistic, self-reliant model of older age is characteristic of certain countries of northern Europe (the UK, Germany, the Netherlands, the Nordic countries) and contrasts with other cultural practices of ageing prevalent in southern Europe, where the family is expected to take primary responsibility. Studies of older migrants often bring this contrast into the open. British retirees who have settled in southern Spain, Malta and the Italian regions of Tuscany and Umbria frequently remark how, in these countries, older people are respected by the young and lovingly cared for within the family circle (King, Warnes and Williams 2000); whilst amongst migrants from southern Europe and the developing world there is often negative surprise at the way old people in northern host societies are marginalised by their families and society and either left to fend for themselves or put in old people's care homes (Ganga 2006; Gardner 2002).

The end-game in this debate on ageing and old age is a fundamental questioning of the utility of these concepts. Bytheway argues that the concept of 'old age' should be re-thought, even discarded, because it is a 'cultural construction' whose 'popular utility' only 'succeeds in sustaining ageism within societies' (1995, 119). The title of the concluding chapter to his 1995 book - 'No more "elderly", no 
Accepted Manuscript (AM) of King, R., Lulle, A., Sampaio, D. and Vullnetari, J. (2016) Unpacking the ageing-migration nexus and challenging the vulnerability trope. Journal of Ethnic and Migration

Studies [DOI: TBC][accepted June 2016; anticipated to be published online August 2016].

more old age' - is provocative and suggests the elimination of these terms, although in his 2000 follow-up paper he argues for a relativist rather than an absolutist terminology or a non-vocabulary: hence 'older people' instead of 'the elderly', and 'later-life' and 'older age' rather than 'old age'.

On the other side of the debate, Andrews (1999) challenges the propensity of some studies on ageing to emphasise 'agelessness', and argues that it is vital to accept old age as a means of reinforcing its importance within society; in other words, in denying old age as a rightful category, one is not reducing but perpetuating the problems arising from an ageist society. Supporting the same premise, Gibson (2000) contends that older people should not endeavour or be encouraged to remain 'young', as that would be a denial of the positive benefits that come with the ageing process respect, wisdom, experience, calmness etc. And the same author maintains that, in the light of long-standing ageist prejudice, words such as 'elderly' need to be rehabilitated rather than tabooed.

\section{Ageing and migration: Intersections and typologies}

We now bring migration and transnationalism into the discussion. The problematique of ageing migrants is a relatively new field and remains marginal in both migration studies and social gerontology. Yet migrants are becoming a substantial component of the ageing population in Western Europe and in other wealthy countries with a history of large-scale post-war immigration (White 2006). Research on ageing can no longer be limited to national-scale analysis since the experience of old age is increasingly shaped by migration and by transnational practices. The conventional view is that being old and having a migration background constitutes a 'double jeopardy' leading to multiple vulnerabilities - weak physical and mental health, low income, poor housing, (self-)exclusion from care and welfare services, and so on (Dowd and Bengston 1978; Fokkema and Naderi 2013). But this is only one side of the ageing-migration coin, and other studies, of wealthy expats and retirement migrants, tell a different story, one of enhanced welfare and well-being (Warnes et al. 1999).

Across all groups of older migrants, there has been a proliferation of overlapping and seemingly interchangeable concepts such as 'active', 'successful', 'positive' and 'good' ageing. There is no space to delve into detail here. The World 
Accepted Manuscript (AM) of King, R., Lulle, A., Sampaio, D. and Vullnetari, J. (2016) Unpacking the ageing-migration nexus and challenging the vulnerability trope. Journal of Ethnic and Migration

Studies [DOI: TBC][accepted June 2016; anticipated to be published online August 2016].

Health Organization defines active ageing as enabling 'people to realize their potential for physical, social, and mental well-being throughout the life course, and to participate in society according to their needs, desires and capacities' (WHO 2012, 12). Fernandez-Ballesteros et al. (2013) make a distinction between 'active ageing' as a health-related term which is useful for planning socio-medical policies, and the broader conceptualisation of 'successful ageing' which includes psychosocial components of 'ageing well'. Another line of debate points to these terms' culturalspecific nature: in an international migration context, such notions need to be continuously negotiated and redefined as people move across borders and simultaneously experience ageing (Torres 2001).

As a final prelude to our typology, we need to pinpoint key changes enmeshed in how ageing and migration are currently configured. These include: increasing ethnic diversity of older people (Biggs and Daatland 2004), growing socio-economic and demographic stratification and differentiation amongst older migrants (Wilson 2000), mounting complexity of transnational mobility patterns (Jackson, Crang and Dwyer 2004), and the enduring significance of place (Andrews and Philips 2005).

Combining and building on the various categorisations suggested by Rowles (1986), Warnes and Williams (2006), Warnes et al. (2004) and Wilson (2000), we arrive at the following typology: older people left behind by migration; older familyjoining migrants; affluent international retirement migrants; older economic migrants; older return migrants; and ageing-in-place migrants.

\section{Older people left behind by migration}

These are not ageing migrants as such, but their lives and well-being are fundamentally impacted by the emigration of their children, especially if all their adult children have departed. Most studies of those 'left behind' by migration focus on young children, but recently there has been a significant growth in research on older people, especially the so-called 'zero generation' - the parents of firstgeneration migrants - with studies from locations as diverse as Albania (King and Vullnetari 2006), Bolivia (Bastia 2009), Australia-Italy (Baldassar 2007) and Canada-Romania (Nedelcu 2009).

In their overview of what they call the 'migration-left behind nexus', Toyota et al. (2007) attempt to bring this category of people back into view, pointing out that 
Accepted Manuscript (AM) of King, R., Lulle, A., Sampaio, D. and Vullnetari, J. (2016) Unpacking the ageing-migration nexus and challenging the vulnerability trope. Journal of Ethnic and Migration

Studies [DOI: TBC][accepted June 2016; anticipated to be published online August 2016].

the migration literature itself has 'left behind the left behind'. One problem with the term 'left behind' is that its very expression is invested with negative images of abandonment, helplessness, absence and loss, and these are indeed the dominant themes in this emergent literature on the elderly non-migrants, seen as passive receivers of remittances and dependent on support and long-distance care from emigrant sons and daughters. Increasingly, however, there are signs that more active roles are being recognised, notably as the carers of left-behind grandchildren (Bastia 2009) and as the managers and investors of remittances in housing and businesses (Vullnetari and King 2011). Where the zero generation are physically separated from their children and grandchildren, their wish to be actively involved in care and support for them (rather than the other way round) is denied by the rupture that long-distance migration brings to family structures, so that much of their apparent passivity is imposed on them.

\section{Follow-the-children migration}

A solution to the problem of loneliness and frustration is for the older generation to follow their children. Recent research on the Albanian case explores some of these dynamics and tensions: the 'zero generation' achieves family recomposition and is able to provide hands-on care to grandchildren but they also find themselves in a 'different' environment (not speaking the language, for example) and may end up suffering social isolation outside the family circle (King et al. 2014).

But there is another important type of family-oriented elderly migration which has hardly been studied yet is sharply revealed in databases on pension payments, such as that from the UK Department for Work and Pensions. This database shows that the number of UK pensions payed to recipients living abroad passed 1 million in 2005 and is growing at 9 per cent per year (compared to the annual growth in the number of UK-national pensioners, 6 per cent); and that two-thirds of these foreignresident UK pensioners were living in (in order of importance) Australia, Canada, the USA, New Zealand and South Africa (King 2012, 291). Warnes et al. (2004) call this group 'family-oriented international retirement migrants' who have relocated abroad to join already-settled children who had earlier migrated for career, lifestyle or marriage reasons to countries 'where Britain had long-established colonial, economic and overseas settlement connections' (Warnes and Williams 2006, 1262). 
Accepted Manuscript (AM) of King, R., Lulle, A., Sampaio, D. and Vullnetari, J. (2016) Unpacking the ageing-migration nexus and challenging the vulnerability trope. Journal of Ethnic and Migration

Studies [DOI: TBC][accepted June 2016; anticipated to be published online August 2016].

However, it often happens that legal barriers impose constraints on the migration of elderly parents. Legal provisions for family reunion often only permit the follow-on of children to join their migrant parents, excluding the 'zero generation'. Hence legal understandings of family life (based on the two-generation nuclear family) are in tension with 'real' family networks of 'lived lives' bound together by intergenerational love and care (Baldassar et al. 2007).

\section{International retirement migration}

This category has obvious overlaps with the family-oriented type discussed above, with the major difference that 'IRM', as it now widely referred to in the literature, involves the migration of older retirees independent of their families, who usually remain in the country of origin. The classic routes for IRM lead from the UK, Germany, the Netherlands and the Nordic countries to Spain, southern France, Italy, Malta and Cyprus. Typical locales for IRM residents to settle in are the Spanish costas and islands such as Majorca and Tenerife, or 'rural idyll' settings such as Provence and Tuscany (Williams, King and Warnes 1997). Perhaps because of the ease and enjoyment of doing fieldwork in such attractive locations, there has been a large amount of research on this type of older migrant (for overviews see CasadoDíaz, Kaiser and Warnes 2004; King 2012).

Most studies describe these older migrants as affluent retirees who usually migrate as couples, trading their valuable metropolitan homes in northern Europe and their occupational pensions for a relaxed lifestyle in pleasant surroundings in a warmer climate where activities such as sunbathing, swimming and golf can be enjoyed for much of the year. Some retirees stay put all year round; others, especially those from Nordic countries, are seasonal movers or 'snowbirds', alternating summer in the north with winter in the south (Gustafson 2001).

However, not all is as idyllic as this form of migration might appear, and there are inherent risks in moving abroad at a later age, even to a place which has been previously visited on holidays. Especially in coastal areas, retirees cluster in singlenationality residential complexes and 'integration' with the local population is minimal. As older people transition from the state of being the 'young, healthy old' to the frail and sick 'old old', problems of health and social care loom large, and the result may be a painful return migration to the country of origin (Hardill et al. 2005; 
Accepted Manuscript (AM) of King, R., Lulle, A., Sampaio, D. and Vullnetari, J. (2016) Unpacking the ageing-migration nexus and challenging the vulnerability trope. Journal of Ethnic and Migration

Studies [DOI: TBC][accepted June 2016; anticipated to be published online August 2016].

Oliver 2008). Or worse, this difficult return may not be possible. The frail retiree may have sold their home-country property and have no relative to care for them; or the sale of their overseas dwelling may be compromised by collapsing house prices (as in Spain during the recession). The result is that they find themselves 'trapped in paradise' as they become increasingly ill and dependent on a local health care system which relies on family support - which the retirees lack.

\section{Older economic migrants}

Like family-oriented retirement migrants, older people who migrate in their $50 \mathrm{Os}$ and 6os as labour migrants are an overlooked group within the typology of ageing migrants. Yet this group has recently started to come to the attention of researchers, both in the US and in Europe. A study of older Filipina care-givers in Los Angeles (Nazareno, Parrenas and Fan 2014) revealed trends to an increasing age at first-time emigration and towards working beyond 'normal' retirement age. This situation reflected both the structural conditions of poverty and unemployment amongst middle-age and older women at home in the Philippines, and the increased attractiveness of older-age employees to the care-receiving clientele in Los Angeles mainly older widows. The average age of care-givers in the 100-person survey was 57.5 years and some respondents were caring for elderly people the same age, or even younger than themselves. However, low wages, difficult living conditions and the lack of possibilities to return home result in these Filipina carers becoming trapped in a situation where 'the unretirable elderly care for the retired elderly' (Nazareno et al. 2014, 25).

The European scenario where older-age, mainly female migration takes place is East-West movement, again associated mainly with care work and low-grade cleaning and service labour. Older women, more so than older men, feel (and are) rejected by the post-socialist market liberalisation which offers them few or no job opportunities yet denies them a decent pension. In one of the few detailed studies of this phenomenon, Boccagni and Ambrosini (2012) document how mature-age women from Eastern Europe have become the fulcrum of the domicile-based care system in Italy. Whilst they find a better income and a measure of satisfaction from their 'useful' work, fundamental ambiguities surround their future and their ability to reconnect with 'home'. 
Accepted Manuscript (AM) of King, R., Lulle, A., Sampaio, D. and Vullnetari, J. (2016) Unpacking the ageing-migration nexus and challenging the vulnerability trope. Journal of Ethnic and Migration

Studies [DOI: TBC][accepted June 2016; anticipated to be published online August 2016].

\section{Older labour migrants who return to their country of origin}

Migrant workers who migrate as young adults, and who decide to stay on in the host country until they approach retirement age, are faced with a dilemma at that point in their lives. For many, the urge to return has remained with them throughout their working lives and the cessation of work would seem to provide them with the perfect opportunity to do so. But in the meantime many life-events have occurred to anchor them in the host country: the birth of children, and perhaps also grandchildren, who have their own educational and career trajectories rooted in their country of upbringing; the acquisition of pensions which may not be portable to the country of origin; and access to health and welfare services that, again, may not be matched in the home country.

Nevertheless, there is a quota of labour migrants who do return, corresponding to what Cerase (1974) calls, in his well-known typology of return migrations, the 'return of retirement'. Other studies document the challenges of reintegration into the home community after so many years working abroad. Nostalgic images of what it will be like 'back home' often do not match the real experience of return, leading to what Ní Laoire (2008) refers to, in the Irish case, as 'narratives of not quite belonging'. Irish elderly returnees, used to a working life in large cities like London or Birmingham, have difficulties adjusting to the slow pace of life in their rural areas of origin, with their scattered and declining populations; as a result they liable to suffer from loneliness and social isolation (Barrett and Mosca 2013).

\section{Ageing-in-place migrants}

This group, quantitatively and policy-wise the most important component of the ageing-migration nexus, at least from a European perspective, is made up largely of individuals (and later their families) who migrated to the industrial economies of North-West Europe for work-related purposes in the twenty years or so between the 1950 and the mid-1970s. The majority came from poverty-stricken rural areas of southern Europe and North Africa, and from former colonies in West Africa, the Caribbean and South Asia. These migrants mainly entered factory and construction work and made little occupational progress throughout their working lives. Following factory closures and mass redundancies as a result of the oil crises and recessions of 
Accepted Manuscript (AM) of King, R., Lulle, A., Sampaio, D. and Vullnetari, J. (2016) Unpacking the ageing-migration nexus and challenging the vulnerability trope. Journal of Ethnic and Migration

Studies [DOI: TBC][accepted June 2016; anticipated to be published online August 2016].

the 1970 and 1980 s, some of these migrants switched to small businesses such as shops and snack bars, usually with long working hours and low profit margins.

The cohort effect of their mass immigration into North-West Europe as young adults in the early postwar decades means that the first generation are now beyond the conventional retirement age; and further ageing will continue to present healthcare and welfare challenges over the next one or two decades (White 2006). Despite the 'healthy migrant effect' (that migrants are a selection of the fittest and most ambitious young adults from the country of origin's population), their harsh working conditions, poor housing and diet and lack of attention to preventive medical checks combine to create health problems in later life. Yet it is dangerous to generalise, since ageing-in-place migrants are markedly heterogeneous, not just in terms of origins and cultural and ethnic characteristics, but also in the extent to which they have raised children and formed social networks at the destination. There is also considerable diversity in their utilisation of, and entitlement to, various welfare, housing, and health-care benefits (Warnes and Williams 2006, 1262).

\section{Ageing in migration: Four positive scenarios}

Whilst we certainly do not want to deny or obscure the disadvantages suffered by ageing migrants in some contexts, we now present biographical sketches of four individuals interviewed as part of research carried out by different members of this paper's author team. Each case illustrates one of the ageing-migration interactions described above. Cyril is an example of 'IRM', Pranvera of follow-the-children migration, Albertino of return migration, and Dagnija of later-life economic migration. All four research subjects used migration to achieve a greater sense of physical and psychosocial well-being, including an enhanced sense of self-worth.

\section{Cyril, the marathon-runner: 'You live longer in Spain'}

Interviewed as part of research into British IRM, Cyril crisply articulated a view widely held by older heliotropic migrants, moving south in search of sunnier, warmer climes, a more relaxed outdoor lifestyle, and a different and more 'genuine' culture and way of life (King et al. 2000). Whether it is true that international retirement migrants live longer than those who stay put is a moot point, for these is no hard statistical or medical evidence available. What is important for our discussion here is 
Accepted Manuscript (AM) of King, R., Lulle, A., Sampaio, D. and Vullnetari, J. (2016) Unpacking the ageing-migration nexus and challenging the vulnerability trope. Journal of Ethnic and Migration

Studies [DOI: TBC][accepted June 2016; anticipated to be published online August 2016].

that people feel they are living 'better' and with an enhanced sense of personal wellbeing. We have chosen Cyril to illustrate how IRM contributes to active and positive ageing because of the contrast between his working life in England and his postretirement life in southern Spain. Most studies on British international retirement see it as a largely middle-class or elite phenomenon linked to lifestyle and the aesthetic of living in a 'character' property in places like Provence, the Dordogne or Tuscany; typical career histories of these migrants are in business, the senior civil service, the professions and the arts (Benson and O'Reilly 2009). Cyril's class and career background is more humble, as belied by his strong 'northern' accent and his more than 40 years working on the nursing staff in - as he put it - 'an institution for the criminally insane' in a large northern English city. He regarded this as a 'shocking and stressful job' ('two of my colleagues got killed in there'), and a contributory factor to the two heart attacks he had suffered in his early 50 .

Cyril's tough working life was alleviated by regular package holidays in Spain with his wife and children. Eventually they bought a modest property on a small urbanización (purpose-built estate) on a hill overlooking the Costa del Sol. His retirement plan was already clear at that time:

I always wanted to live here. I had a bee in my bonnet about Spain, long before I came here. I intended to retire to this country. I wanted sunshine! I had been putting money aside to buy a house in Spain eventually... I bought the house long before I actually came to live in it... We used it for holidays. I have a large family... we all came here from time to time, also my friends.

The estate had been built by a Swedish developer and most of Cyril's neighbours were retired Swedes who spent the winter in Spain and the summer in Sweden (cf. Gustafson 2001). Aged in his early 70 s when interviewed, Cyril lived here all year round, apart from visiting his children in England at Christmas. Now widowed, he supplemented his pension by doing paid work tending the estate's communal gardens.

Gardening was not the only physical activity Cyril engaged in. With a certain macho pride he described how, when his doctor advised him to rest after his second heart attack, he took up jogging: 'I have done three marathons! I do weight-lifting, I 
Accepted Manuscript (AM) of King, R., Lulle, A., Sampaio, D. and Vullnetari, J. (2016) Unpacking the ageing-migration nexus and challenging the vulnerability trope. Journal of Ethnic and Migration

Studies [DOI: TBC][accepted June 2016; anticipated to be published online August 2016].

go to the local gym, I get reduced rates because of my age... There are mainly Spanish people there, and some Swedes... I mix with all of them, young people too'.

Unlike most British retirees in southern Spain, who socialise almost exclusively amongst themselves and speak little or no Spanish even after several years of living there (O'Reilly 2000), Cyril had taken positive steps towards integrating with the local Spanish population. For the past two years he had been following Spanish language courses for foreigners at the local university, and he had teamed up with a local Spanish student who was learning English and they practice conversation together so that both can improve the other's language. To cap it all, Cyril was also a member of a dancing club which met in a local hotel, where he had become skilled in some Spanish dances too.

Cyril, then, is our example of positive ageing in a context of IRM. We do not hold him up necessarily as any kind of 'ideal'; others will have different scenarios for an enjoyable life of ageing and international retirement abroad - perhaps a dolce far niente lifestyle, doing sweet nothing, turning the relaxing holiday experience into a permanent way of life. Not that Cyril was above a spot of relaxation, as this final quote from his narrative account reveals:

If I am not working here or doing other things, I can sit outside in the sun, go for a swim, or sit with a coffee on the promenade... You live longer in Spain. Life is easier all round, you don't fret if people are late... I don't even wear a watch any more.

\section{Pranvera, the 'flying grandmother': 'I want to teach them Albanian'}

Earlier in the paper we quoted the case of Albania as exemplary of the phenomenon of older generations 'left behind' by their migrating adult children. The degree and scale of this abandonment, exacerbated by the fact that, in many instances, all the children (and grandchildren) are abroad, has become an issue of major national social concern, with reports of older people foraging for survival on a near-starvation diet of broth made from grass, weeds and herbs (Vullnetari and King 2008). For others, remittances from emigrant children ensure adequate material well-being, but a devastating loss of locally-based transgenerational care and intimate family relations occurs. Profoundly upsetting for elderly Albanians has been the denial of 
Accepted Manuscript (AM) of King, R., Lulle, A., Sampaio, D. and Vullnetari, J. (2016) Unpacking the ageing-migration nexus and challenging the vulnerability trope. Journal of Ethnic and Migration

Studies [DOI: TBC][accepted June 2016; anticipated to be published online August 2016].

the practice of active grandparenting, seen as their very raison d'être, as it had been in decades when, under the communist regime, mobility was tightly controlled and the various members of most extended families lived in close spatial proximity to one another. Given this history of immobility and banned emigration before 1991, it is no surprise that Albanians virtually exploded out of their formerly isolated country in the 1990s, mainly heading for nearby Greece and Italy. But much of this early migration was irregular and achieved via smuggling networks: this meant that return visits could not easily take place, nor could the older generation visit their children abroad since visas were impossible to acquire without bribery or 'connections'. Things started to change towards the end of the 1990s when both Italy and Greece instituted major legalisation schemes for irregular migrants, and Albanian migration also spread to other European countries, notably the UK, or aspiring migrants sought success in the US diversity visa lottery scheme, which was attractive to skilled migrants.

Pranvera, in her mid-50s when she was interviewed in a village in southern Albania in 2004, was about to follow her daughters to the US, where they had been living with their Albanian husbands for the past few years. Both daughters had two young children. Pranvera's son, and her husband Selami, had both been short-term emigrants doing seasonal work in Greece, but the son had resettled in the village, having landed a job with the local police. Meanwhile Selami and Pranvera worked their small farm - they grew wheat, vegetables and apples and had a cow and a calf. In this first extract from her interview, Pranvera describes the typical situation of thousands of residual rural families in Albania:

You can't make a decent living from farming... Here you have to sell your produce by yourself... there are no markets, no [price] security... So for us, if we didn't have emigration, we wouldn't be able to survive. Without having migration in the family, it is not possible to live well, build a house or make a home.

Pranvera's daughters were both well-educated, one in economics and marketing, the other in medicine. Both won the diversity lottery and went to live in the US, working respectively in an architectural practice and in nursing. Both had emigrated soon 
Accepted Manuscript (AM) of King, R., Lulle, A., Sampaio, D. and Vullnetari, J. (2016) Unpacking the ageing-migration nexus and challenging the vulnerability trope. Journal of Ethnic and Migration Studies [DOI: TBC][accepted June 2016; anticipated to be published online August 2016].

after marrying, and their children were raised in the US. Pranvera's husband had been to Detroit (where the daughters lived) on an extended visit to help out and earn some money working 'off the books' in a local car-wash. Now the daughters were applying for family reunion to bring the parents over. In the meantime Pranvera lamented their absence so far away:

We miss them so much, but we are happy that they are working and making a good living. They have their jobs, their husbands, their children. But yes, we miss them; they are not here to join in a celebration or in case of a disaster.

Looking to the future:

God willing, the reply comes soon, so that we can unite with them. And then we can be together... we can help them and the children... so they can improve their standard of living. I want to teach the grandchildren Albanian, because they hardly know it at all... I am not able to speak to my grandchildren on the phone. They [the children's parents] do not have time to teach them, because they are so busy at work.

But Pranvera and her husband also have their own elderly parents living close by, so they are a kind of 'sandwich generation' with care responsibilities and aspirations both to their parents, and children and grandchildren. Important to note here, then, is not the left-behind zero generation as dependent care receivers, but as active and aspiring care givers.

There is an update to the situation recorded above. Soon after the interview, Pranvera and Selami joined their daughters in Detroit. Later, their son and his family also joined them, and they were able to live as one big extended family. Living with their son (as is the Albanian patrilineal custom), Pranvera looks after the grandchildren, speaking with them in Albanian, and Selami does part-time work. Pranvera and Selami flew to Albania to visit their own parents and other relatives every two years, although Pranvera's mother had since died. 
Accepted Manuscript (AM) of King, R., Lulle, A., Sampaio, D. and Vullnetari, J. (2016) Unpacking the ageing-migration nexus and challenging the vulnerability trope. Journal of Ethnic and Migration

Studies [DOI: TBC][accepted June 2016; anticipated to be published online August 2016].

\section{Albertino, the winemaker from the Azores: 'Here there is just peace and quiet'}

Like many small islands and archipelagos, the Azores have long been a platform for emigration, especially to Canada and the USA. Emigration was intense during the period between the 1950 s and the 1980 s, prompted by population pressure, unemployment and natural disasters; latterly return migration has been the dominant trend (Rocha, Ferreira and Mendes 2011). Some returnees come back upon retirement, others when they are still of working age. But the intersections between work, retirement, and return are often blurred, as in the case of Albertino, who emigrated to Canada in his mid-20s and returned to the Azores in his 40s, in a kind of pre-retirement move; except that for him 'retirement' involves farming, winemaking and, even now, in his late 6os, getting up at 5am every morning!

Like most Azorean migrants, Albertino's working life in Canada was tough. $\mathrm{He}$ worked on building sites and on road construction:

The worst thing [about working in Canada] was the very harsh winters, because I always worked outside. The lorry would start at 7 in the morning and wouldn't stop until 5 in the afternoon... I persevered, worked really hard, made a lot of money... If I hadn't have gone to Canada, I wouldn't have anything of what I have now.

Yet his narrative is one of true belonging to his Azorean homeland. The well-being that he has experienced over the twenty years or so since his return is palpable, and closely related to his idea of returning home sooner or later, although his Azorean wife, whom he met and married in Canada, and their only-child daughter were less keen.

Albertino had prepared meticulously for his return: he bought a house, some pasture for cattle and, most important of all, he constructed a cellar for his winemaking passion. Born and raised on an island famed for its viticulture and having inherited vineyards from his father, he always dreamt of having his own vindima (grape harvest) and adega (wine-making cellar). As Albertino conducted a guided tour of his beloved cellar, he talked about the many feasts his family held there, especially after the vindima: 
Accepted Manuscript (AM) of King, R., Lulle, A., Sampaio, D. and Vullnetari, J. (2016) Unpacking the ageing-migration nexus and challenging the vulnerability trope. Journal of Ethnic and Migration Studies [DOI: TBC][accepted June 2016; anticipated to be published online August 2016].

Oh, we organise many feasts in the wine cellar... you should see how many people would gather here... New Year, more than 60 people - all our family and friends! We have dinner, sing, dance, there are firecrackers...

And unlike some returned Azoreans who experience difficulties adjusting to the slow pace of life (Rocha et al. 2011, 211-213), Albertino relishes his island dream of a quiet life:

I didn't experience any shock at all. On the contrary, I felt very good here. Here there is just peace and quiet. We leave the house and all the doors are left open - in Canada it wasn't like this.

Even though now 'officially' retired and drawing his pension, his daily routine has hardly changed since he first returned:

To stop is to die; to work is to live. I wake at 5 every morning; I just cannot stay in bed. Today, at $5 \mathrm{am}$, I was up and drinking my coffee... Then my grandchildren come at 7.30 to have breakfast on their way to school... I go feed my animals, my chickens, then I go to the vineyard... I always have something to do!

Albertino presents a picture of active ageing in a context of an always-planned return to the homeland after a period of hard manual labour in tough climatic conditions abroad. But this emigrant work was well-paid and was instrumental in enabling Albertino to return to his dream of a comfortable farming way of life - a return of nostalgia and of conservatism (Cerase 1974). He comes over as a contented man surrounded by his family, and his vineyard, on his island.

\section{Dagnija and erotic agency: 'I never had an orgasm in Latvia'}

In Latvia, and throughout much of Eastern Europe, getting a job, and perhaps too a pension, abroad are the driving forces behind the emigration of older women whose situation at home is dire on multiple levels. In these post-socialist societies, ageing 
Accepted Manuscript (AM) of King, R., Lulle, A., Sampaio, D. and Vullnetari, J. (2016) Unpacking the ageing-migration nexus and challenging the vulnerability trope. Journal of Ethnic and Migration

Studies [DOI: TBC][accepted June 2016; anticipated to be published online August 2016].

women are considered of no value. The new marketised economy based on sales and services favours the employment of younger, more 'attractive' bodies. Meanwhile, pensions have been eroded to minimal amounts in the wake of welfare cuts implemented in response to the 2008 financial crisis, which was particularly severe in Latvia. The average monthly pension in Latvia was 230 euros in 2010, rising to 264 in 2014, nowhere near enough to live on, and three-quarters of pensioners live below the official poverty line.

These economic motives for migration are often accompanied by more personal considerations: older women, particularly those who are widowed, divorced or separated, can find satisfying and liberating personal relations and intimate lives after migrating to the UK or elsewhere. From a sense of being devalued, non-sexual older beings, ageing women feel younger, stronger, more attractive and appreciated after migrating to the UK, even if the only jobs they can access are in care work, cleaning or agricultural production and processing. Their developing sense of selfworth is built upon their work and their economic independence, but also in many cases on their sexual re-awakening and their recovery of what Mimi Sheller (2012) calls their 'erotic agency'. Sheller is at pains to point out that erotic agency is not just about physical sexuality, but more a praxis of 'embodied freedom' which 'encompasses a wider realm of feeling and the sensual' and 'all forums of selfdetermination of one's bodily relation to time, space, and movement' (2012, 244, 279).

Accession to the EU in 2004, the devastating economic and welfare impact of the 2008 banking collapse, and the devaluing of older women (except in a grandmother role) were the main structuring factors for the out-migration of ageing Latvian women over recent years. Since the recession Latvia has had one of the highest emigration rates in Europe, reflecting both the high unemployment rate and the lure of the UK as an open market for all kinds of work. Dagnija, now in her late50s, is a typical illustration. She arrived in a market town in Eastern England in 2009 and her main objective was getting a job and working towards a UK pension, after which she would retire back to Latvia to 'a small house, near to a forest'. This sylvan vision is compromised by where her friends and relatives will be in the future. Recently her two sons, including a newly-born granddaughter, had moved to England, whilst her daughter was in Latvia. 
Accepted Manuscript (AM) of King, R., Lulle, A., Sampaio, D. and Vullnetari, J. (2016) Unpacking the ageing-migration nexus and challenging the vulnerability trope. Journal of Ethnic and Migration

Studies [DOI: TBC][accepted June 2016; anticipated to be published online August 2016].

Pension is the most important thing in my life here, I will stay at least until I receive a pension. Then, I want to return to Latvia... I will build a small house, near to a forest, not a big house, I want a small, cosy one, with a small garden... But maybe I will be very lonely in Latvia, and where will my children and grandchildren be?

But our main reason for selecting Dagnija is her personal journey of erotic (in the broad sense explained by Sheller) self-discovery. Her former husband, whom she repeatedly described as 'a disgusting man' who drank heavily and beat her, had died several years ago. She is currently in a partnership with a Latvian man in the town where she is living, but this relationship is foundering and she expressed her frustration thus: 'It is incredibly difficult to get a NORMAL Latvian man... Maybe I just need to calm down, but I DON'T WANT to calm down, I want more and better!'

This quote led into the part of the interview where she talked more explicitly about her desires and sexuality: a clear vindication of her erotic sensibilities and her strong wish to be 'noticed' as an attractive woman. In the food processing factory where she worked she had to wear a uniform so that 'nobody can tell if I am a man or a woman'.

But on my free days, I dress up to go into town, to go to the shops... high heels, bright dresses, full make-up. And then I see that people like how I look... people look at me, say compliments... I feel positive, I feel good... I feel I am an attractive woman, a woman who is desirable [...] I can tell you openly that I am a woman who never achieved orgasm in Latvia; with no man, good or bad. But now I have found a way how I can satisfy myself and I am fine, I am OK about this... Actually I am a crazy woman, I can really do crazy things; my spark has not yet burned out.

Dagnija seems caught between her nostalgic idea of a quiet return to rural Latvia and her ongoing journey of erotic self-discovery in England, a trip which, her last utterance reveals, is still a work in progress. Her case is a powerful illustration of the 'sexual turn' in migration studies (Mai and King 2009) which draws out into the open issues relating to love, sexuality and desire as salient factors in migration decision-making and behaviour. 
Accepted Manuscript (AM) of King, R., Lulle, A., Sampaio, D. and Vullnetari, J. (2016) Unpacking the ageing-migration nexus and challenging the vulnerability trope. Journal of Ethnic and Migration

Studies [DOI: TBC][accepted June 2016; anticipated to be published online August 2016].

\section{Conclusion and policy issues}

Especially within Europe, ageing and migration are two of the most important sociodemographic trends; perhaps the most important. Yet little is known about how they combine. This paper has provided an overview of some of the key issues relating to ageing populations with a migratory background, moving from the definition and conceptualisation of the core issue of ageing and then setting out a typology of ageing-migration intersections. Whilst we acknowledge that, for many older migrants, there are serious challenges to their well-being because of their vulnerable social position and lack of various forms of capital, we have also been at pains to point out the danger of exaggerating the vulnerability trope. There are many circumstances where being a migrant in later life can be a rational choice or outcome; a life-stage which is fulfilling, enjoyable, even liberating and empowering.

Thus far, policies to cope with the specific issues pertaining to ageing migrants are little developed, although one must bear in mind the variety of ageing-migration contexts documented above. Host-country policies geared towards the needs of ageing-in-place or later-life economic or follow-the-children migrants are likely to be different to those catering for return migrants or affluent international retirement migrants; but in all cases there is a policy vacuum, and initiatives are highly localised. International retirement migrants are generally welcomed by the authorities and businesses in the areas where they settle, for they bring in purchasing power through their savings and pensions. In areas of dense IRM settlement, such as the Spanish Costa del Sol, local offices with multilingual staff act as advice bureaux, and the local hospitals and health services also have doctors with appropriate language skills (King et al. 2000, 189-192). Former labour migrants who return to their home countries upon retirement are not seen as requiring any specific policy beyond healthcare services appropriate to an ageing population, and perhaps assistance with overseas pensions.

The key policy challenges relate to ageing-in-place labour migrants, both those who are retired and those who remain economically active. Whilst there is abundant evidence that the 'double jeopardy' of being both old and a migrant operates to create vulnerability through low incomes, poor housing, language barriers, social isolation and a working life of health-sapping labour (eg. Bolzmann et al. 2004; Fokkema and Naderi 2013), there may be other features of older migrants' lives which cushion 
Accepted Manuscript (AM) of King, R., Lulle, A., Sampaio, D. and Vullnetari, J. (2016) Unpacking the ageing-migration nexus and challenging the vulnerability trope. Journal of Ethnic and Migration

Studies [DOI: TBC][accepted June 2016; anticipated to be published online August 2016].

them against these vulnerabilities. Most important here is the family context: living in a multi-generation co-resident family is likely to provide care and support in a protective environment - although in a minority of cases, this could be a space where abuse of older people is hidden. The immigrant family setting may be socially isolated from the wider host-society context, but this may be compensated by solidarity networks and friendship groups with other co-ethnics.

On the whole, policies geared towards the specific needs of older migrants are both deficient and beset by contradictions and injustices. A key dimension concerns the legal and policy stance of the host country towards older migrants' rights to various kinds of social welfare, including social housing and long-term health care. As Ackers and Dwyer (2002) have extensively documented, the circumstances and entitlement to welfare of elderly migrants are profoundly connected to questions of their citizenship, length of residence, labour market history and social insurance payments record. These principles and criteria overlap and also conflict with each other, with the result that arbitrary and unfair distinctions are thrown up between eligible (deserving) and ineligible (undeserving) older people. Within Europe, the most common category of the 'ineligible' are third-country-nationals. According to Warnes et al. (2004, 322), the 'contradiction that should be exposed' is the case where a state promotes the immigration of labour, thereby de facto acknowledging that the migrant workers make a valuable economic contribution, yet that state does not fully honour its commitment to recognising that the migrants will eventually become sick and/or old and need treatment at least equal to that received by hostcountry citizens.

Having said that, it is important not to draw up policies that only regard older migrants as passive, state-dependent individuals, but instead recognise the resources that they embody - as active carers and as potentially economically active. Of course, there is also the opposite danger of seeing older people instrumentally as a resource to be capitalised, ignoring their diverse needs and subjective sense of well-being.

A final policy contradiction is that between different social models of ageing. The dominant policy norm in Western societies is the concept of 'active ageing' creating better conditions to encourage the elderly to enjoy a good quality of life, preferably independently. The success of this policy model in having a real impact on people's lives is debatable. Equally debatable is the extent to which this model can be 
Accepted Manuscript (AM) of King, R., Lulle, A., Sampaio, D. and Vullnetari, J. (2016) Unpacking the ageing-migration nexus and challenging the vulnerability trope. Journal of Ethnic and Migration

Studies [DOI: TBC][accepted June 2016; anticipated to be published online August 2016].

transferred to older migrants from different cultures. Whilst the general principle of enabling older people, of whatever background, to achieve maximum well-being is incontrovertible, there are culturally-specific interpretations of what successful ageing and well-being in old age actually mean (Torres 2001). But there is a further danger here, which Torres (2006) observes in Sweden, whereby an almost excessive attention to the perceived needs of older immigrants leads to their cultural essentialisation and homogenisation, resulting in their socially constructed problematisation as an 'Other' in Swedish society. On a broader European and international scale, policies for successful ageing which combine nuanced understandings of how a positive and enjoyable old age is shaped in different cultural contexts are little developed and need sensitive consultation with the many diverse groups involved.

\section{References}

Ackers, Louise, and Peter Dwyer. 2002. Senior Citizenship? Retirement, Migration and Welfare in the European Union. Bristol: Policy Press.

Andrews, Molly. 1999. "The Seductiveness of Agelessness." Ageing and Society 19 (3): 301-318.

Andrews, Gavin J., and David Phillips, eds. 2005. Ageing and Place. London: Routledge.

Baldassar, Loretta. 2007. "Transnational Families and Aged Care: The Mobility of Care and the Migrancy of Ageing." Journal of Ethnic and Migration Studies 33 (2): 275-297.

Baldassar, Loretta, Cora Vellekoop Baldock, and Raelene Wilding. 2007. Families Caring across Borders: Migration, Ageing and Transnational Caregiving. New York: Palgrave MacMillan.

Barrett, Alan, and Irene Mosca. 2013. "Social Isolation, Loneliness and Return Migration: Evidence from Older Irish Adults." Journal of Ethnic and Migration Studies 39 (10): 1659-1677.

Bastia, Tanja. 2009. "Women's Migration and the Crisis of Care: Grandmothers Caring for Grandchildren in Urban Bolivia." Gender and Development 17 (3): 389-401. 
Accepted Manuscript (AM) of King, R., Lulle, A., Sampaio, D. and Vullnetari, J. (2016) Unpacking the ageing-migration nexus and challenging the vulnerability trope. Journal of Ethnic and Migration

Studies [DOI: TBC][accepted June 2016; anticipated to be published online August 2016].

Benson, Michaela, and Karen O’Reilly. 2009. "Migration and the Search for a Better

Way of Life: A Critical Exploration of Lifestyle Migration.” The Sociological

Review 57 (4): 608-625.

Biggs, Simon. 1997. "Choosing not to be Old? Masks, Bodies and Identity

Management in Later Life.” Ageing and Society 17 (5): 553-570.

Biggs, Simon, and Svein Daatland, eds. 2004. Ageing and Diversity. London: Policy Press.

Boccagni, Paolo, and Maurizio Ambrosini. 2012. Cercando il benessere nelle migrazioni. Milan: FrancoAngeli.

Bolzman, Claudio, Raffaella Poncioni-Derigo, Marie Vial, and Rosita Fibbi. 2004.

“Older Labor Migrants' Well-Being in Europe: The Case of Switzerland.” Ageing and Society 24 (3): 411-429.

Bytheway, Bill. 1995. Ageism. Buckingham: Open University Press.

Bytheway, Bill. 2000. "Youthfulness and Agelessness: A Comment." Ageing and Society 20 (6): 781-789.

Bytheway, Bill. 2005. “Ageism and Age Categorization.” Journal of Social Issues 61 (2): 361-374.

Casado-Díaz, María A., Claudia Kaiser, and Anthony M. Warnes. 2004. "Northern European Retired Residents in Nine Southern European Areas: Characteristics, Motivations and Adjustments." Ageing and Society 24 (3): 353-381.

Cerase, Francesco P. 1974. "Migration and Social Change: Expectations and Reality. A Study of Return Migration from the United States to Italy.” International Migration Review 8 (2): 245-262.

Dowd, James J., and Vern L. Bengtson. 1978. "Aging in Minority Populations: An Examination of the Double Jeopardy Hypothesis.” Journal of Gerontology 33 (3): $427-436$.

Featherstone, Mike, and Mike Hepworth. 1989. "Ageing and Old Age: Reflections on the Postmodern Life Course." In Booming and Being Old: Sociological Approaches to Later Life, edited by Bytheway, Bill, Teresa Kiel, Patricia Allat, and Alan Bryman, 143-157. London: Sage.

Fernandez-Ballesteros, Rocio, Maria A. Molina, Rocio Schettini, and Marta Santacreu. 2013 “The Semantic Network of Ageing Well.” In Annual Review of Gerontology and Geriatrics. Vol. 33, Healthy Longevity, A Global Approach, 
Accepted Manuscript (AM) of King, R., Lulle, A., Sampaio, D. and Vullnetari, J. (2016) Unpacking the ageing-migration nexus and challenging the vulnerability trope. Journal of Ethnic and Migration

Studies [DOI: TBC][accepted June 2016; anticipated to be published online August 2016].

edited by Robine, Jean-Marie, Carol Jagger, and Eileen Crimmins, 79-108. New York: Springer.

Fokkema, Tineke, and Robert Naderi. 2013. "Differences in Late-Life Loneliness: A Comparison between Turkish and Native-Born Older Adults in Germany." European Journal of Ageing 10 (4): 289-300.

Ganga, Deianira. 2006. "From Potential Returnees into Settlers: Nottingham's Older Italians." Journal of Ethnic and Migration Studies 32 (8): 1395-1413.

Gardner, Katy. 2002. Age, Narrative and Migration: The Life Course and Life Histories of Bengali Elders in London. Oxford: Berg.

Gibson, H.B. 2000. "It Keeps Us Young." Ageing and Society 20 (6): 773-779.

Gustafson, Per. 2001. Retirement Migration and Transnational Lifestyles.” Ageing and Society 21 (4): 371-394.

Hardill, Irene, Jacqui Spradbery, Judi Arnold-Boakes, and Maria L. Marrugat. 2005. Severe Health and Social Care Issues amongst British Migrants who Retire to Spain." Ageing and Society 25 (5): 769-783.

Harper, Sarah, and Glenda Laws. 1995. "Rethinking the Geographies of Ageing." Progress in Human Geography 19 (2): 199-221.

Jackson, Peter, Philip Crang, and Claire Dwyer, eds. 2004. Transnational Spaces.

London: Routledge.

King, Russell. 2012. Sunset Migration. In An Introduction to International

Migration Studies, edited by Martinello, Marco, and Jan Rath, 281-304. Amsterdam: Amsterdam University Press.

King, Russell, Eralba Cela, Tineke Fokkema, and Julie Vullnetari. 2014. The Migration and Well-Being of the Zero Generation: Transgenerational Care, Grandparenting and Loneliness amongst Albanian Older People. Population, Place and Space 20 (8): 728-738.

King, Russell, and Julie Vullnetari. 2006. "Orphan Pensioners and Migrating Grandparents: The Impact of Mass Migration on Older People in Rural Albania." Ageing and Society 26 (5): 783-816.

King, Russell, Anthony M. Warnes, and Allan M. Williams. 2000. Sunset Lives. British Retirement Migration to the Mediterranean. Oxford: Berg Publishers. Mai, Nicola, and Russell King. 2009. "Love, Sexuality and Migration: Mapping the Issue(s)." Mobilities 4 (3): 295-307. 
Accepted Manuscript (AM) of King, R., Lulle, A., Sampaio, D. and Vullnetari, J. (2016) Unpacking the ageing-migration nexus and challenging the vulnerability trope. Journal of Ethnic and Migration Studies [DOI: TBC][accepted June 2016; anticipated to be published online August 2016].

Nazareno, Jennifer P., Rahcel S. Parrenas, and Fan, Yung-Kang. 2014. Can I Ever Retire? The Plight of Migrant Filipino Caregivers in Los Angeles. Los Angeles: UCLA Institute for Research on Labor and Employment.

Nedelcu, Mihaela. 2009. “La 'génération zéro': du sédentaire à l'acteur circulant. Effets de mobilité sur la génération des parents des migrants roumains hautement qualifiés à Toronto à l'ère du numérique." In Les circulations transnationales.

Lire les turbulences migratoires contemporaines, edited by Geneviève Cortes, and Laurent Faret, 187-198. Paris: Armand Colin.

Neugarten, Bernice L. 1974. "Age Groups in American Society and the Rise of the Young-Old." Annals of the American Academy of Political and Social Science 415: 187-198.

Ní Laoire, Catríona. 2008. "Complicating Host-Newcomer Dualisms: Irish Return Migrants as Home-Comers or Newcomers?” Translocations 4 (1): 35-50.

Oliver, Caroline. 2008. Retirement Migration: Paradoxes of Ageing. London: Routledge.

O'Reilly, Karen. 2000. The British on the Costa del Sol: Transnational Identities and Local Communities. London: Routledge.

Pain, Rachel, Graham Mowl, and Carol Talbot. 2000. "Difference and the Negotiation of 'Old Age'." Society and Space 18 (3): 377-393.

Rocha, Gilberta P.N., Eduardo Ferreira, and Derrick Mendes. 2011. Between Two Worlds: Emigration and Return to the Azores. Azores: Government of the Azores and University of the Azores.

Rowles, Graham D. 1986. "The Geography of Ageing and the Aged: Toward an Integrated Perspective." Progress in Human Geography 10 (4): 511-539.

Schwanen, Tim, Irene Hardill, and Susan Lucas. 2012. "Spatialities of Ageing: The Co-Construction and Co-Evolution of Old Age and Space." Geoforum 43 (6): 1291-1295.

Sheller, Mimi. 2012. Citizenship from Below: Erotic Agency and Caribbean Freedom. Durham NC: Duke University Press.

Torres, Sandra. 2001. "Understandings of Successful Ageing in the Context of Migration: The Case of Iranian immigrants to Sweden." Ageing and Society 21 (3): 333-355. 
Accepted Manuscript (AM) of King, R., Lulle, A., Sampaio, D. and Vullnetari, J. (2016) Unpacking the ageing-migration nexus and challenging the vulnerability trope. Journal of Ethnic and Migration

Studies [DOI: TBC][accepted June 2016; anticipated to be published online August 2016].

Torres, Sandra. 2006. "Elderly Immigrants in Sweden: 'Otherness' under

Construction.” Journal of Ethnic and Migration Studies 32 (8): 1341-1358.

Toyota, Mika, Brenda S.A. Yeoh, and Liem Nguyen. 2007. "Bringing the 'Left Behind'

Back into View in Asia: A Framework for Understanding the 'Migration-Left

Behind Xexus'." Population, Space and Place 13 (3): 157-161.

Vullnetari, Julie, and Russell King. 2008. “'Does your Granny Eat Grass?' On Mass

Emigration, Care Drain and the Fate of Older People in Rural Albania." Global

Networks, 8 (2): 139-171.

Vullnetari, Julie, and Russell King. 2011. Remittances, Gender and Development:

Albania's Society and Economy in Transition. London: I.B. Tauris.

Warnes, Anthony M., Klaus Friedrich, Leonie Kellaher, and Sandra Torres. 2004.

"The Diversity and Welfare of Older Migrants in Europe." Ageing and Society 24

(3): 307-326.

Warnes, Anthony M., Russell King, Alan M. Williams, and Guy Patterson. 1999. "The

Well-Being of British Expatriate Retirees in Southern Europe." Ageing and

Society 19 (6): 717-740.

Warnes, Anthony, and Allan M. Williams. 2006. "Older Migrants in Europe: An

Innovative Focus for Migration Studies.” Journal of Ethnic and Migration Studies

32 (8): $1257-1281$.

White, Paul. 2006. "Migrant Populations Approaching Old Age: Prospects in Europe.”

Journal of Ethnic and Migration Studies 32 (8): 1283-1300.

WHO. 2002. Active Ageing: A Policy Framework. Geneva: World Health

Organization.

Williams, Allan M., Russell King, and Anthony M. Warnes. 1997. "A Place in the Sun:

International Retirement Migration from Northern to Southern Europe."

European Urban and Regional Studies 4 (2): 115-134.

Wilson, Gail. 2000. Understanding Old Age: Critical and Global Perspectives.

London: Sage. 